\title{
Solubility and Surface Adsorption Characteristics of Metal Oxides to High Temperature
}

\author{
D.J. Wesolowski, M.L. Machesky, S.E. Ziemniak, C. Xiao, \\ D.A. Palmer, L.M. Anovitz, P. Bénézeth
}

This report was prepared as an account of work sponsored by the United States Government. Neither the United States, nor the United States Department of Energy, nor any of their employees, nor any of their contractors, subcontractors, or their employees, makes any warranty, express or implied, or assumes any legal liability or responsibility for the accuracy, completeness or usefulness of any information, apparatus, product or process disclosed, or represents that its use would not infringe privately owned rights.

\section{NOTICE}


SOLUBILITY AND SURFACE ADSORPTION CHARACTERISTICS OF METAL OXIDES TO HIGH TEMPERATURE. D.J. Wesolowski', M.L.Machesky ${ }^{2}$, S.E. Ziemniak ${ }^{3}$, C. Xiao ${ }^{4}$, D.A. Palmer', L.M. Anovitz ${ }^{\mathrm{t}}$ and P. Bénézeth', '(Oak Ridge National Laboratory, P.O. Box 2008, Oak Ridge, TN 37831-6110, wesolowskid@ornl.gov), ${ }^{2}$ (Illinois State Water Survey, 2204 Griffith Dr. Champaign, IL 61820-7495), '3 (Lockheed Martin Corp., P.O. Box 1072, Schenectady, NY), ${ }^{4}$ (BetzDearborn Div., Hercules, Inc., P.O. Box 3002, Trevose, PA 19053).

Introduction: The interaction of high temperature aqueous solutions with mineral surfaces plays a key role in many aspects of fossil, geothermal and nuclear energy production. This is an area of study in which the subsurface geochemical processes that determine brine composition, porosity and permeability changes, reservoir integrity, and fluid flow rates overlap with the industrial processes associated with corrosion of metal parts and deposition of solids in pipes and on heat exchanger surfaces. The sorption of ions on mineral surfaces is also of great interest in both the subsurface and "above ground" regimes of power production, playing a key role in subsurface migration of contaminants (nuclear waste disposal, geothermal brine re-injection, etc.) and in plant operations (corrosion mitigation, migration of radioactive metals from reactor core to heat exchanger, etc.). In this paper, results of the solubility and surface chemistry of metal oxides relevant to both regimes are summarized.

Solubility Studies: The equilibrium solubilities and dissolution mechanisms of magnetite and the $\mathrm{Fe}-\mathrm{Zn}$-Co chromite spinels have been investigated from room temperature to $300^{\circ} \mathrm{C}$ at pressures near vapor saturation and over a wide range of $\mathrm{pH}$ 's. The total metal content of aqueous solutions in equilibrium with these solids is rigorously related to the hydrolysis speciation of the metals in solution. Figure (1) shows the solubility of magnetite, $\mathrm{Fe}_{3} \mathrm{O}_{4}$, as determined by equilibrating powdered magnetite with an aqueous solution of sodium trifluoromethanesulfonate (NaTr, 0.1 molal ionic strength) at $250^{\circ} \mathrm{C}$ under 15 bars of $\mathrm{H}_{2}$ gas pressure, in one of ORNL's hydrogen-electrode concentration cells. These cells permit direct measurement of the hydrogen ion concentration $\left(\mathrm{pH}_{\mathrm{m}} \equiv-\log \left[\mathrm{H}^{+}\right]\right.$) of the solution during a titration, which can last up to several weeks in duration. As can be seen, excellent agreement is obtained with the recent experimental studies of Tremaine and LeBlanc [1] and Ziemniak et al [2] near the solubility minimum, whereas the earlier experimental studies of Sweeton and Baes [3] and the recent modeling efforts of Shock et al [4] indicate anomalously high dissolved iron concentrations under neutral and high $\mathrm{pH}$ conditions. The shapes of the solubility profiles in Fig. (1) are dictated by the congruent, equilibrium dissolution of magnetite according to the reaction

$$
1 / 3 \mathrm{Fe}_{3} \mathrm{O}_{4, \mathrm{~s}}+2 \mathrm{H}_{\text {aq }}^{+}+1 / 3 \mathrm{H}_{2, \mathrm{~g}} \Leftrightarrow \mathrm{Fe}^{2+}{ }_{\mathrm{aq}}+4 / 3 \mathrm{H}_{2} \mathrm{O}
$$

together with the hydrolysis of ferrous iron in solution via the stepwise reactions $(y=1-3)$

$$
\mathrm{Fe}^{2+}{ }_{\mathrm{aq}}+\mathrm{yH}_{2} \mathrm{O} \Leftrightarrow \mathrm{Fe}(\mathrm{OH})_{\mathrm{y}}{ }^{2-\mathrm{y}}{ }_{\mathrm{aq}}+\mathrm{yH}^{+}{ }_{\mathrm{aq}}
$$

Ferric iron species are insignificant in solution at this hydrogen gas pressure. At lower $\mathrm{pH}$ and temperature, magnetite appears to dissolve by an incongruent dissolution mechanism 
$\mathrm{Fe}_{3} \mathrm{O}_{4, \mathrm{~s}}+2 \mathrm{H}_{\text {aq }}^{+} \Leftrightarrow \mathrm{Fe}_{2} \mathrm{O}_{3, \mathrm{~s}}+\mathrm{Fe}^{2+}{ }_{\text {aq }}+\mathrm{H}_{2} \mathrm{O}$

producing well-crystallized hematite $\left(\mathrm{Fe}_{2} \mathrm{O}_{3}\right)$ as a solid phase, in addition to magnetite (Figure 2). This has been confirmed by $\mathrm{X}$-ray diffraction analysis of the run products. The closed symbols in Fig. (2) represent samples collected during "forward" titrations, in which an $\mathrm{NaOH}+\mathrm{NaTr}$ solution is titrated into a more alkaline $\mathrm{NaTr}+\mathrm{HTr}$ solution. The open symbols represent the results of the associated "reverse" titration, in which the $\mathrm{pH}$ was shifted back to a more acidic condition by the addition of an $\mathrm{NaTr}+\mathrm{HTr}$ titrant. The heavy solid curve in Fig. (2) is the equilibrium concentration of iron predicted by reactions $(2,3)$ above, using the aqueous iron speciation model of [2], and neglecting the fact that hematite is thermodynamically unstable relative to magnetite under such strongly reducing conditions. Clearly, these results indicate that reaction (3) is metastably reversible under these conditions, in experiments lasting up to several weeks.

For the chromite spinels, Ziemniak et al [5] have observed that total iron concentrations in aqueous solutions in apparent equilibrium with $\mathrm{Fe}(\mathrm{II}) \mathrm{Cr}(\mathrm{III})_{2} \mathrm{O}_{4}$ exceeded the total dissolved chromium by several orders of magnitude, dictating that a residual, $\mathrm{Cr}$-rich phase is left on the surface of the starting material. These authors argued that $\gamma-\mathrm{CrOOH}$ is the residual phase formed, and presented equations describing the free energies, as a function of temperature (25$290^{\circ} \mathrm{C}$ ), for the reactions

$$
\begin{aligned}
& \mathrm{CrOOH}_{\mathrm{s}}+\mathrm{H}_{2} \mathrm{O} \Leftrightarrow \mathrm{Cr}(\mathrm{OH})_{3, \mathrm{aq}} \\
& \mathrm{Cr}(\mathrm{OH})_{3, a q}+\mathrm{H}_{2} \mathrm{O} \Leftrightarrow \mathrm{Cr}(\mathrm{OH})_{4, \mathrm{aq}} \cdot+\mathrm{H}^{+}
\end{aligned}
$$

At near-neutral to basic pH's, these are the only two aqueous chromium(III) species needed to describe the solubility of $\gamma-\mathrm{CrOOH}$ [5]. Studies at ORNL have now been completed on the solubilities of $\mathrm{ZnCr}_{2} \mathrm{O}_{4}$ and $\mathrm{CoCr}_{2} \mathrm{O}_{4}$ over a similar $\mathrm{pH}$ and temperature range, and representative results are shown in Figures $(3,4)$. These studies utilized a flow-through, packed-column cell, conceptually similar to that used by Ziemniak et al [5], but with much lower flow rates, length:diameter ratios, and longer solution residence times than in the earlier study. In these studies, it was found that equations $(4,5)$, using the free energy functions of [5], accurately predicted the total chromium concentrations in solution in equilibrium with both phases, with chromium levels in the sub-nanomolal range and only weakly-dependent on $\mathrm{pH}$ or temperature. Furthermore, as was found in the case of $\mathrm{FeCr}_{2} \mathrm{O}_{4}$ [5], the total divalent metal concentration in solution greatly exceeded that of the total chromium. The divalent metal concentrations could be accurately predicted from the reactions

$$
\mathrm{Me}(\mathrm{II}) \mathrm{Cr}_{2} \mathrm{O}_{4, \mathrm{~s}}+2 \mathrm{H}_{\mathrm{aq}}^{+} \Leftrightarrow \mathrm{Me}^{2+}{ }_{\mathrm{aq}}+2 \mathrm{CrOOH}_{\mathrm{s}}
$$

and the metal hydrolysis reactions

$$
\mathrm{Me}^{2+}{ }_{\text {aq }}+\mathrm{yH}_{2} \mathrm{O} \Leftrightarrow \mathrm{Me}(\mathrm{OH})_{y}^{2 \cdot y}{ }_{\text {aq }}+\mathrm{yH}^{+}
$$

where $\mathrm{Me}$ stands for $\mathrm{Zn}$ or $\mathrm{Co}$ and $\mathrm{y}$ ranges from 1 to 3 . Data for the $\mathrm{Zn}^{2+}$ hydrolysis reactions were taken from Bénézeth et al [6] and for $\mathrm{Co}^{2+}$ from Ziemniak et al [7]. There is substantial 
scatter in the observed total $\mathrm{Zn}$ and Co concentrations shown in Figures $(3,4)$, but note that the solubilities of these metals are in the parts-per-trillion range (ppt) in equilibrium with their respective chromites. Thus, analytical uncertainty becomes a major factor, due to contamination as well as detection limits. Magnetic-sector ICP-MS proved to be the most reliable method of analysis of $\mathrm{Zn}$ and $\mathrm{Co}$ at these levels, although multiple-injection graphite-furnace AA (Zeeman focus) and evaporative preconcentration techniques could also be used. For chromium analyses at the picomolal levels predicted from reactions $(4,5)$, a new chemiluminescence technique was developed [8], which proved equivalent to graphite furnace and ICP-MS methods, but which used much less expensive equipment. Even sub-ppt levels of $\mathrm{Cr}$ could be detected with 10-30\% reproducibility by chemiluminescence.

Surface Charge and Ion Adsorption Studies: Terminal oxygen atoms at metal oxide surfaces react with water, forming hydroxylated sites that impart a $\mathrm{pH}$-dependent surface charge. The association of solution counterions with this modified surface results in a complex structure, termed the Electrical Double Layer (EDL). Surface charge influences colloid transport and flocculation, adsorption of ions from solution, mineral dissolution/precipitation rates, growth morphologies, and other interfacial phenomena. Hydrogen-electrode concentration cells (HECC's) have been used at ORNL to conduct potentiometric titrations of $\mathrm{H}^{+}$(or $\mathrm{OH}^{-}$) adsorption and desorption on rutile $\left(\mathrm{TiO}_{2}\right)$ and magnetite $\left(\mathrm{Fe}_{3} \mathrm{O}_{4}\right)$ powder surfaces in 0.01 to 1.0 molal NaCl, tetramethylammonium chloride (TMACl) and NaTr media from 25 to $290^{\circ} \mathrm{C}$ at $\mathrm{pH}$ 's of 3 to 10 [911]. These are the first such direct potentiometric studies of the protonation of mineral surfaces ever performed at temperatures greater than $95^{\circ} \mathrm{C}$.

Because $\mathrm{H}^{+}$(and/or $\mathrm{OH}^{-}$) binding with terminal oxygen atoms is considered the surfacecharge-determining reaction for oxide particles in aqueous solutions, potentiometric titrations of powdered minerals under conditions of known solution and solid masses and surface areas, known titrant compositions and masses, and continuously-monitored $\mathrm{pH}_{\mathrm{m}}$ allow determination of the proton-induced surface charge. The difference between the measured $\mathrm{pH}_{\mathrm{m}}$ and that calculated solely from a mixture of the starting and titrant solutions, is computed in terms of micromoles of excess $\mathrm{H}^{+}$in solution per square meter of mineral surface exposed to the solution. This is then converted to surface charge density via the relationship

$\sigma_{0} \equiv \sigma_{\mathrm{H}}=-\mathrm{F}\left(\mu\right.$ moles excess $\left.\mathrm{H}^{+}\right) / \mathrm{m}^{2}$

where $\mathrm{F}$ is the Faraday constant $(0.0965$ Coulombs/ $\mu$ equivalent $)$. The negative sign indicates that a positive value of excess $\mathrm{H}^{+}$in solution corresponds to net proton release from the surface, whereas a deficit of $\mathrm{H}^{+}$in solution results from proton uptake by the solid, resulting in positive surface charge. Because this proton-induced surface charge is confined to a fixed plane, positive or negative surface charge buildup is inhibited by electrostatic repulsion between adjacent, likecharged sites on the surface. Counterions of opposite charge in the aqueous phase partially shield this surface charge build-up, resulting in the EDL. This effect gives rise to the typical relationship of oxide surface titrations at constant temperature, but for various concentrations of an electrolyte, such as $\mathrm{NaCl}, \mathrm{KNO}_{3}$, etc., as shown for rutile at $100^{\circ} \mathrm{C}$ in $\mathrm{NaCl}$ and tetramethylammonium (TMA) chloride solutions in Figure (5). The $\mathrm{pH}$ plotted in this and subsequent figures is converted to the activity scale using the activity coefficient model discussed in [10]. The 
"proton sorption isotherms" increase in slope with increasing ionic strength, but exhibit a common intersection point. This " $\mathrm{pH}_{\text {cip }}$ ", in the case of truly "indifferent" electrolytes with symmetrical binding of the cation and anion on negatively or positively-charged surfaces, respectively, is coincident with the point of zero charge, " $\mathrm{pH}_{\mathrm{pzc}}$ " of the surface. The fact that the sorption isotherms for rutile in $\mathrm{TMACl}$ media are significantly shallower than in $\mathrm{NaCl}$ media, indicates that the much larger $\mathrm{TMA}^{+}$cation is less effective at shielding negative surface charge buildup than $\mathrm{Na}^{+}$.

In Figure (6), the proton sorption isotherms for magnetite in 0.03 and 0.3 molal NaTr solutions at $100^{\circ} \mathrm{C}$ are shown, expressed in terms of excess $\mathrm{H}^{+}$in solution, rather than surface charge. Several features of the magnetite isotherms are distinct from those of rutile. First, there is a sharp downturn in the isotherms at low $\mathrm{pH}$, which is due to proton consumption by dissolution of this much more soluble phase, releasing $\mathrm{Fe}^{2+}$ into solution. Second, the $\mathrm{pH}_{\text {cip }}$ values do not correspond to the condition of nearly zero excess $\mathrm{H}^{+}$in solution. This was also true of our earlier studies of rutile surface protonation, using a solid phase that had not been pretreated hydrothermally in pure water at $220^{\circ} \mathrm{C}$ for a week or more [9]. This hydrothermal pretreatment was avoided in the case of magnetite, in order to minimize oxidation of the surface. The effect of dissolution of the solid phase complicated the interpretation of the $\mathrm{pH}_{\mathrm{cip}}$ values for magnetite, such that a derivative analysis was performed to determine the $\mathrm{pH}$ of minimum slope in the $0.03 \mathrm{~m}$ $\mathrm{NaTr}$ isotherms at each temperature, which were then assumed to reflect the $\mathrm{pH}_{\mathrm{pzc}}$ of the solid.

The $\mathrm{pH}_{\mathrm{pzc}}$ of rutile and magnetite as a function of temperature are compared in Figure (7). The temperature dependencies of the $\mathrm{pH}_{\mathrm{pzc}}$ values for these solids are strikingly similar, and also nearly identical to the temperature dependence of the neutral $\mathrm{pH}$ in pure water $\left(1 / 2 \mathrm{pK}_{\mathrm{w}}\right)$. The curves are estimates calculated from a temperature extrapolation [12] of the revised MUSIC model [13], which involves estimation of the undersaturation of bond valence of surface oxygen atoms bonded to one, two or three metal ions in the underlying oxide crystal lattice. The densities and partial charges of these surface sites are determined from detailed structural analysis of the oxide phase. Surface protonation constants $\left(\mathrm{K}_{\mathrm{Hy}}\right)$ are estimated in the MUSIC model [13] using the relationship,

$\log \mathrm{K}_{\mathrm{Hy}}=-\mathrm{A}^{25}\left(\mathrm{~V}+\Sigma \mathrm{s}_{\mathrm{Me-O}}+\mathrm{m}\left(\mathrm{s}_{\mathrm{H}}\right)+\mathrm{n}\left(1-\mathrm{s}_{\mathrm{H}}\right)\right)$

where $\mathrm{A}^{25}$ is the slope obtained from regression of a large number of logK values for homogeneous protonation reactions of oxygen-bearing aqueous species at $25^{\circ} \mathrm{C}$, versus the undersaturation of charge on the oxygen ligand. $\mathrm{V}$ is the valence of oxygen $(-2.0), \Sigma \mathrm{s}_{\mathrm{Me}-\mathrm{O}}$ is the sum (one, two or three for single, double or triple coordination, respectively) of the bond valence values for the metal-oxygen bonds (Me-O) of interest, $\mathrm{m}$ is the number of donating $\mathrm{H}$-bridges with adsorbed water (requires the presence of an $\mathrm{H}$ atom in the deprotonated, negatively charged species), $\mathrm{s}_{\mathrm{H}}$ is the bond valence of an adsorbed proton $(+0.8)$, and $\mathrm{n}$ is the number of accepting $\mathrm{H}$-bridges with adsorbed water. For singly coordinated surface oxygens $(m+n)=2$, for doubly coordinated surface oxygens $(m+n)=1$ or 2 , and for triply coordinated surface oxygens $(m+n)=1$. The $s_{\text {Meo }}$ values were computed using the Brown bond valence approach.

The $\mathrm{A}^{25}$ parameter was estimated from the protonation constants of a wide range of aqueous species, such as $\mathrm{Fe}(\mathrm{OH})_{3}{ }^{\circ}$ aq $+\mathrm{H}^{+} \Leftrightarrow \mathrm{Fe}(\mathrm{OH})_{2}{ }^{+}+\mathrm{H}_{2} \mathrm{O}$ and $\mathrm{H}_{3} \mathrm{SiO}_{4}{ }^{-}+\mathrm{H}^{+} \Leftrightarrow \mathrm{H}_{4} \mathrm{SiO}_{4}{ }_{\text {aq }}$, taking into account the electrical work involved in neutralization of the negative charge for the latter type of 
reaction. A similar approach was used in the calculation of $\mathrm{A}^{\mathrm{T}}$ parameters at temperatures other than $25^{\circ} \mathrm{C}$ by assuming that all terms in parentheses in eq. (9) are temperature-independent. However, for aqueous species, the average coordination number $(\mathrm{CN})$, used to calculate $\mathrm{s}_{\mathrm{Me}-\mathrm{o}}=$ $\mathrm{z} / \mathrm{CN}$, where $\mathrm{z}$ is the central metal ion charge, was allowed to decrease with increasing temperature, using an empirical relationship derived from spectroscopic studies. From analysis of the available and reliable data on high temperature aqueous reactions, the A parameter in eq. (9) is closely approximated by

$\mathrm{A}^{\mathrm{T}}=-3.877+6189.15 / \mathrm{T}+0.016191(\mathrm{~T})$,

where $T$ is the absolute temperature. Using this equation and the partial charges on the various surface sites, the average $\mathrm{pH}_{\mathrm{pzc}}$ values for the bulk oxide particles were estimated for rutile and magnetite, as shown by the curves in Fig. (7); and found to be well within the experimental uncertainty in the $\mathrm{pH}_{\mathrm{pzc}}$ values. In order to experimentally calibrate the extrapolation to high temperature, the individual site densities were allowed to vary slightly, in order to match the observed $\mathrm{pH}_{\mathrm{pzc}}$ values at $25^{\circ} \mathrm{C}$.

Also shown in Fig. (7) are the experimentally-derived $\mathrm{pH}_{\mathrm{pzc}}$ values from surface $\mathrm{pH}$ titrations of $\mathrm{NiFe}_{2} \mathrm{O}_{4}$, another inverse spinel isostructural with magnetite. However, SEM images of the magnetite used by [11] revealed that the 110 (dodecahedral) and cube (100) faces were predominant, with the 111 (octahedral) face only weakly developed (Figure 8). In contrast, the $\mathrm{NiFe}_{2} \mathrm{O}_{4}$ powder used in this study (Figure 9) consists of particles with the octahedral face highly developed, and with only minor amounts of the cube face expressed. The MUSIC model predicts that for a given surface site, the proton binding constants for magnetite and nickel ferrite are similar, since the ionic radii of $\mathrm{Fe}^{2+}$ and $\mathrm{Ni}^{2+}$ are similar. However, the same model predicts that different crystal faces of either mineral will have very different surface sites, site densities and average $\mathrm{pH}_{\mathrm{pzc}}$ values. As shown in Fig. (7), the MUSIC model reasonably approximates the observed $\mathrm{pH}_{\mathrm{pzc}}$ of nickel ferrite with the morphology shown in Fig. (9).

Specific Ion Adsorption Studies: Ridley et al [14] reported results on the sorption of $\mathrm{Ca}^{2+}$ on rutile powder surfaces as a function of $\mathrm{pH}$, ionic strength and temperature to $250^{\circ} \mathrm{C}$. Figure (10) shows the profound effect of trace amounts of a divalent cation on the proton-induced surface charge of a metal oxide, relative to that of an "inert" electrolyte $(\mathrm{NaCl})$. In fossil power plant steam cycles, ammonia is frequently used as a $\mathrm{pH}$ buffer to mitigate corrosion. Therefore, it is of interest to know if either $\mathrm{NH}_{3}$ or its protonated form, $\mathrm{NH}_{4}{ }^{+}$, significantly influences the surface charge of metal oxides likely to form in this environment, beyond that of its effect on the solution $\mathrm{pH}$ and ionic strength. A large number of experiments have been conducted in 0.03 molal $\mathrm{NaTr}$ on the effect of ammonia on magnetite and nickel ferrite surface charge, with Figure (11) showing some typical results for magnetite. These studies indicate that, after accounting for the change in solution proton balance due to dissociation of $\mathrm{NH}_{4}{ }^{+}$, the surface charge of magnetite is approximately the same in $\mathrm{NaTr}$ solutions of the same $\mathrm{pH}$, temperature and ionic strength, in solutions containing zero to more than $100 \mathrm{ppm}$ total ammonia. This suggests that $\mathrm{NH}_{4}{ }^{+}$interacts with the charged spinel surfaces similarly to $\mathrm{Na}^{+}$. In order to confirm this observation, experiments were conducted on magnetite surface charge in 0.30 molal $\mathrm{LiCl}, \mathrm{NaCl}, \mathrm{KCl}$, and TMACl solutions at temperatures up to $200^{\circ} \mathrm{C}$. The ionic radii of these monovalent cations are 70,102 , 
138 and 280 picometers, respectively, whereas $\mathrm{NH}_{4}^{+}$has an ionic radius of $148 \mathrm{pm}$. These results indicated that negative surface charge density on magnetite increases strongly for a given $\mathrm{pH}$, temperature and ionic strength in $\mathrm{LiCl}$ solutions and decreases moderately in TMACl solutions, relative to $\mathrm{NaCl}$ and $\mathrm{KCl}$ solutions which exhibited nearly identical surface charge. Since $\mathrm{NH}_{4}^{+}$is much closer in radius to $\mathrm{K}^{+}$than $\mathrm{TMA}^{+}$, these results tend to confirm the observation that $\mathrm{NH}_{4}^{+}$interaction with spinel surfaces can be modeled by $\mathrm{Na}^{+}$or $\mathrm{K}^{+}$interactions. It is not practical to conduct surface titrations at very high concentrations of ammonia, since proton balance calculations become intractably uncertain.

Conclusions: These studies demonstrate the complexity of mixed-metal oxide solubility and surface charge characteristics in natural and industrial hydrothermal solutions. The temperatureextrapolated MUSIC model [12] provides a powerful approach for estimating the surface charge of individual crystal faces of metal oxides at high temperature, but more studies are needed on a variety of metal oxides with different atomic structures and crystal morphologies. Also, the incongruent dissolution and precipitation mechanisms of mixed-metal oxides must be further investigated in order to develop a reliable predictive capability of elemental transport, permeability changes and phase transformations in hydrothermal regimes.

Acknowledgment: This research was sponsored by the U.S. Department of Energy, under contract DE-AC05-00OR22725, Oak Ridge National Laboratory, managed by and operated by UTBattelle, LLC.

\section{References:}

[1] P.R. Tremaine and Jacques C. LeBlanc, "The solubility of magnetite and the hydrolysis and oxidation of $\mathrm{Fe}^{2+}$ in water to $300^{\circ} \mathrm{C}^{\prime}$, J. Sol. Chem., Vol. 9, pp. 415-442, 1980.

[2] S.E. Ziemniak, M.E. Jones and K.E.S. Combs, "Magnetite solubility and phase stability in alkaline media at elevated temperatures", J. Sol. Chem., Vol. 24, pp. 837-887, 1995.

[3] F.H. Sweeton and C.F. Baes, Jr., "The solubility of magnetite and hydrolysis of ferrous ion in aqueous solutions at elevated temperatures", J. Chem. Therm., Vol. 2, pp. 479-500, 1970.

[4] E.L. Shock, D.C. Sassani, M. Willis, and D.A. Sverjensky, "Inorganic species in geologic fluids: Correlations among standard molal thermodynamic properties of aqueous ions and hydroxide complexes" Geochim. Cosmochim. Acta, Vol. 61, pp. 907-950, 1997.

[5] S.E. Ziemniak, M.E. Jones and K.E.S. Combs, "Solubility and phase behavior of $\mathrm{Cr}$ (III) oxides in alkaline media at elevated temperatures", $J$. Sol. Chem., Vol. 27, pp. 33-66, 1998.

[6] P. Bénézeth, D.A. Palmer, and D.J. Wesolowski, "The solubility of zinc oxide in $0.03 \mathrm{~m} \mathrm{NaTr}$ as a function of temperature, with in situ pH measurement", Geochim. Cosmochim. Acta, v. 63, pp 1571-1586, 1999.

[7] S.E. Ziemniak, M.A. Goyette and K.E.S. Combs, "Cobalt(II) oxide solubility and phase stability in alkaline media at elevated temperatures", J. Sol. Chem., v. 28, pp. 809-835, 1999.

[8] C. Xiao, D.W. King, D.A. Palmer and D.J. Wesolowski, "Study of enhancement effects in the chemiluminescence method for $\mathrm{Cr}$ (III) in the $\mathrm{ng} \mathrm{l}^{-1}$ range", Anal. Chim. Acta, v. 415, pp. 209-219, 2000.

[9] M.L. Machesky, D.A. Palmer and D.J. Wesolowski, "Hydrogen ion adsorption at the rutile-water interface to $250^{\circ} \mathrm{C}^{\prime \prime}$, Geochim. Cosmochim. Acta, y. 58, pp. 5627-5632, 1994.

[10] M.L. Machesky, D.J. Wesolowski and D.A. Palmer, "Potentiometric titrations of rutile suspensions to $250^{\circ} \mathrm{C}$ ", J. Colloid Interface Sci, v. 200, pp. 298-309, 1998.

[11] D.J. Wesolowski, M.L. Machesky, D.A. Palmer and Lawrence M. Anovitz, "Magnetite surface charge studies to $290^{\circ} \mathrm{C}$ from in situ pH titrations", Chem. Geology, v. 167, pp. 193-229, 2000.

[12] M.L. Machesky, D.J. Wesolowski, D.A. Palmer and M.K. Ridley, "On the temperature dependence of intrinsic surface protonation equilibrium constants: an extension of the revised MUSIC model", $J$. Colloid Interface Sci. (in press). 
[13] T. Hiemstra, P. Venema and W.H. Van Riemsdijk, "Intrinsic proton affinity of reactive surface groups of metal (hydr)oxides: The bond valence principle", J. Colloid Interface Sci, v. 184, pp. 680-692, 1996.

[14] M.K. Ridley, M.L. Machesky, D.J. Wesolowski and D.A. Palmer,"Ca(II) adsorption at the rutile-water interface: A potentiometric study in $\mathrm{NaCl}$ media to $250^{\circ} \mathrm{C}$ ", Geochim. Cosmochim. Acta, v. 63, pp. 3087-3096, 1999. 


\section{Figure Captions:}

Figure 1. Experimental measurements of the solubility of magnetite in $0.1 \mathrm{~m} \mathrm{NaTr}$ at $250^{\circ} \mathrm{C}$ (open symbols), compared with solubilities calculated from the results of [1-4].

Figure 2. Experimental measurements of the solubility of magnetite in $0.1 \mathrm{~m} \mathrm{NaTr}$ at $150^{\circ} \mathrm{C}$, compared with solubilities calculated from the results of [1-4]. Filled symbols represent samples taken during forward titration to higher $\mathrm{pH}$ values. Open symbols represent samples taken during the back titration to lower $\mathrm{pH}$ values.

Figure 3. Total zinc in solution sampled downstream from a packed column of $\mathrm{ZnCr}_{2} \mathrm{O}_{4}$ at 100 bars pressure and temperatures ranging from 150 to $300^{\circ} \mathrm{C}$. Solution $\mathrm{pH}$ was buffered by addition of $\mathrm{NH}_{3}$, as indicated. Solid curves were computed from equations $(6,7)$ as discussed in the text.

Figure 4. Total cobalt in solution in equilibrium with $\mathrm{CoCr}_{2} \mathrm{O}_{4}$ at 100 bars and $250^{\circ} \mathrm{C}$, with $\mathrm{pH}_{\mathrm{m}}$ controlled by ammonia addition. Open symbols and error bars represent sample analyses and their uncertainties. The solid curves represent solubilities calculated from equations $(6,7)$ and dashed curves indicate uncertainty range in the thermodynamic quantities used to calculate the solubilities.

Figure 5. Experimentally-determined surface charge of rutile in $\mathrm{NaCl}$ and $\mathrm{TMACl}$ media at the ionic strengths indicated, and $100^{\circ} \mathrm{C}$. Smooth curves represent model fits to the data, as discussed by [10].

Figure 6. Magnetite surface protonation isotherms at $100^{\circ} \mathrm{C}$ in 0.03 and 0.30 molal $\mathrm{NaTr}$ solutions as a function of $\mathrm{pH}$.

Figure 7. Observed $\mathrm{pH}_{\mathrm{pzc}}$ values of rutile, magnetite and nickel ferrite (open symbols), compared with calculated values from a temperature extrapolation of the revised MUSIC modeI $[12,13]$.

Figure 8. SEM image of a magnetite particle used in the study of [11], compared with the expected form of a magnetite crystal with the dodecahedral (110), cube (100) and octahedral (111) faces present in the proportions 50:40:10.

Figure 9. SEM image of nickel ferrite particles used in this study, compared with the expected form of a nickel ferrite crystal with the dodecahedral (110), cube (100) and octahedral (111) faces present in the proportions 0:10:90.

Figure 10. Surface charge of rutile in 0.03 and $0.3 \mathrm{molal} \mathrm{NaCl}$, and in solutions at $0.03 \mathrm{molal}$ ionic strength $\left(\mathrm{NaCl}\right.$ ) containing $0.001 \mathrm{molal} \mathrm{CaCl}_{2}$, at 25 and $250^{\circ} \mathrm{C}$, showing the combined effects of temperature, ionic strength and specific ion binding on the surface charge development as a function of $\mathrm{pH}$. Intersections of the isotherms in pure $\mathrm{NaCl}$ media mark the $\mathrm{pH}_{\mathrm{pzc}}$ values at 25 and $250^{\circ} \mathrm{C}$.

Figure 11. Proton sorption isotherm of magnetite in 0.03 molal $\mathrm{NaTr}$ (black circles and solid curve), compared with identical solutions containing 21-104 ppm total ammonia at the same ionic strength. 


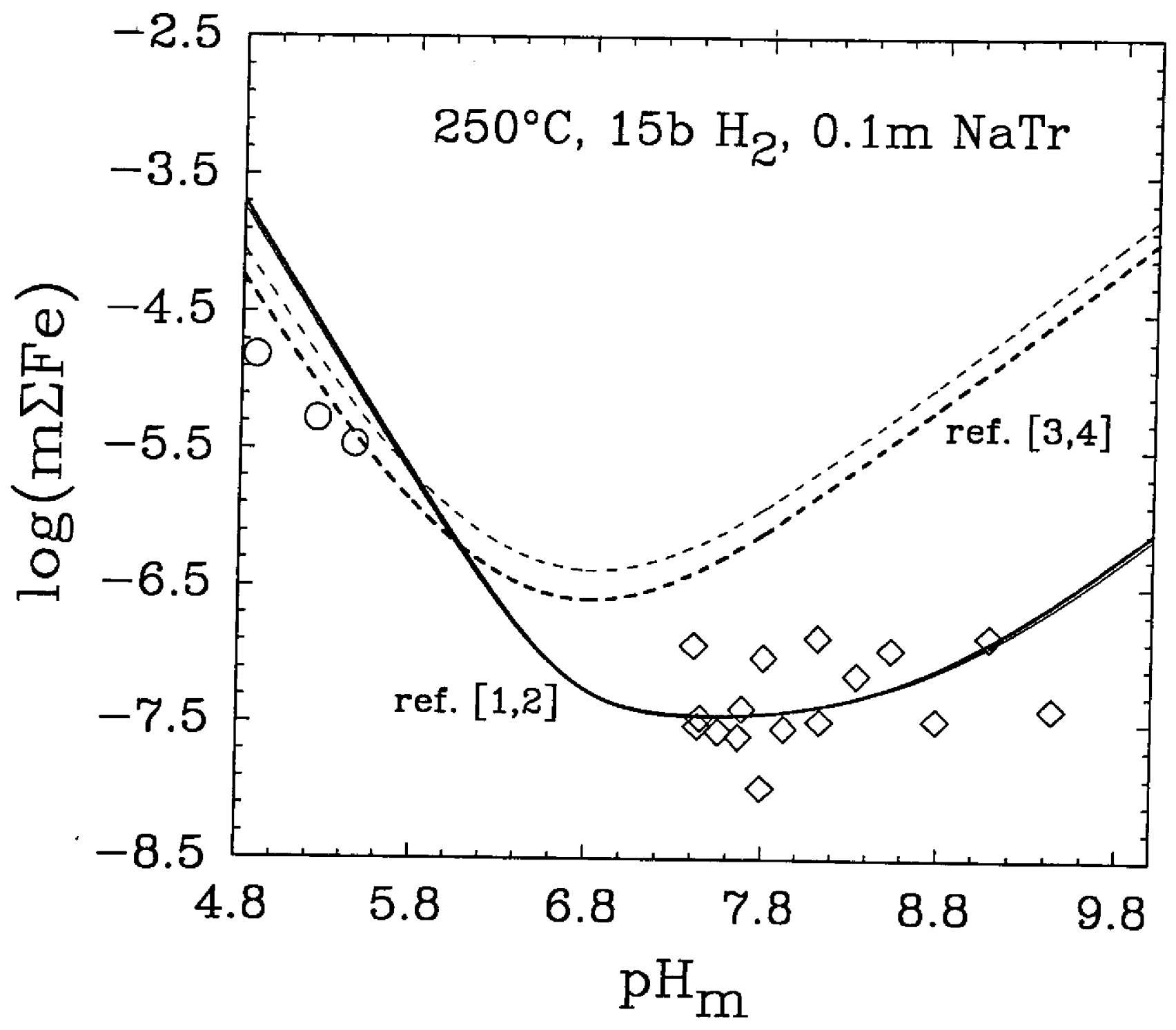




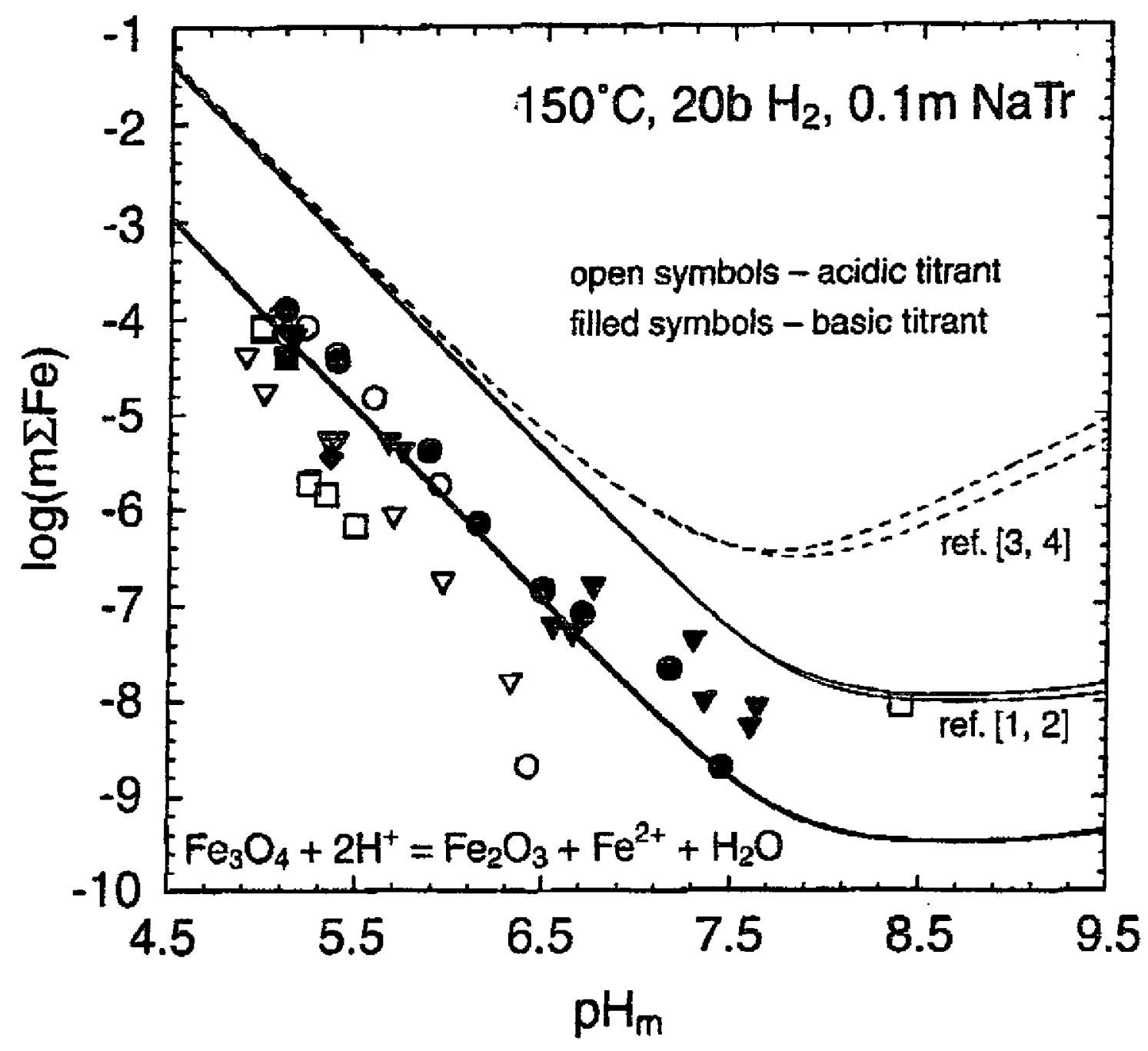

Figure 2 


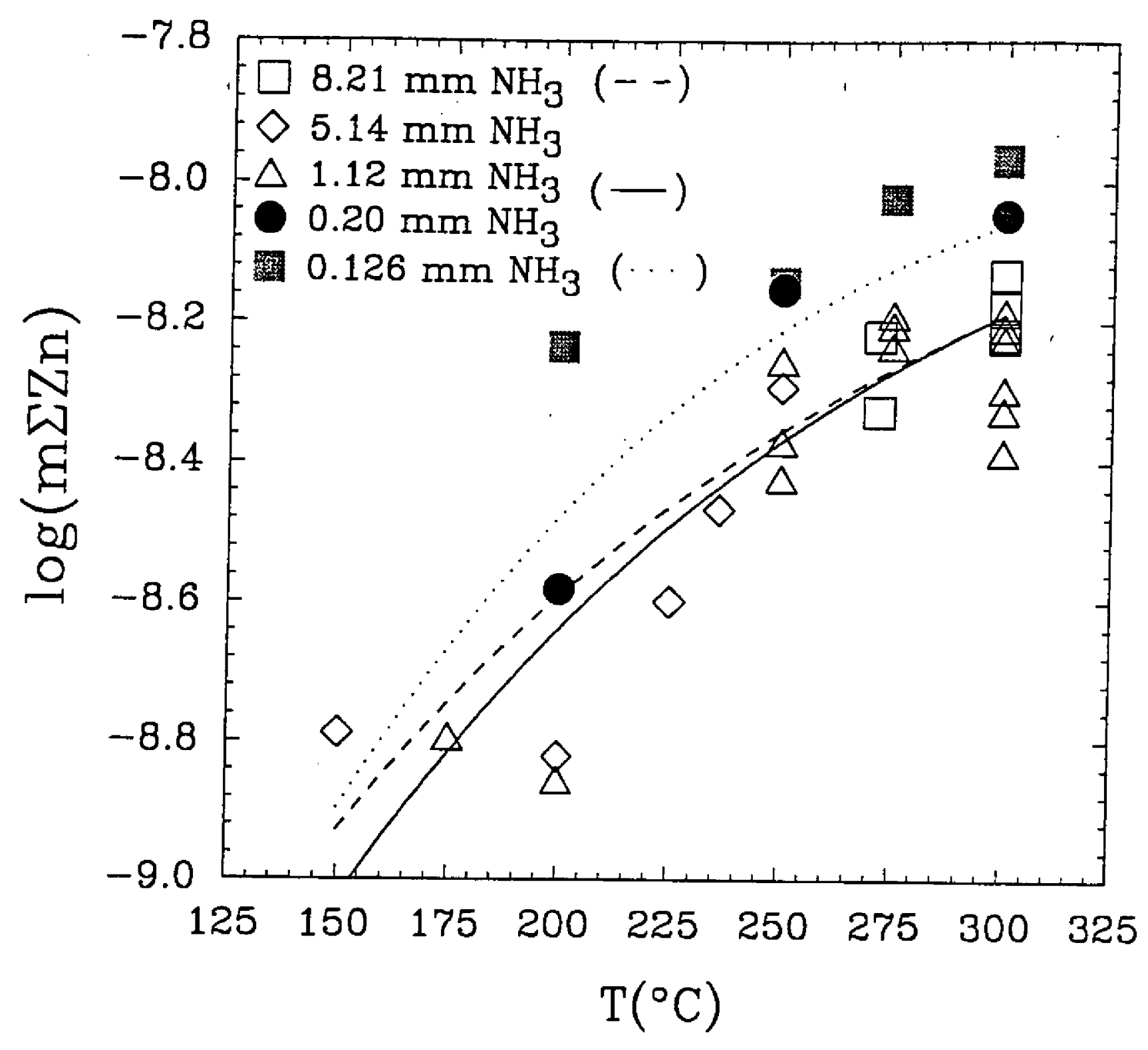




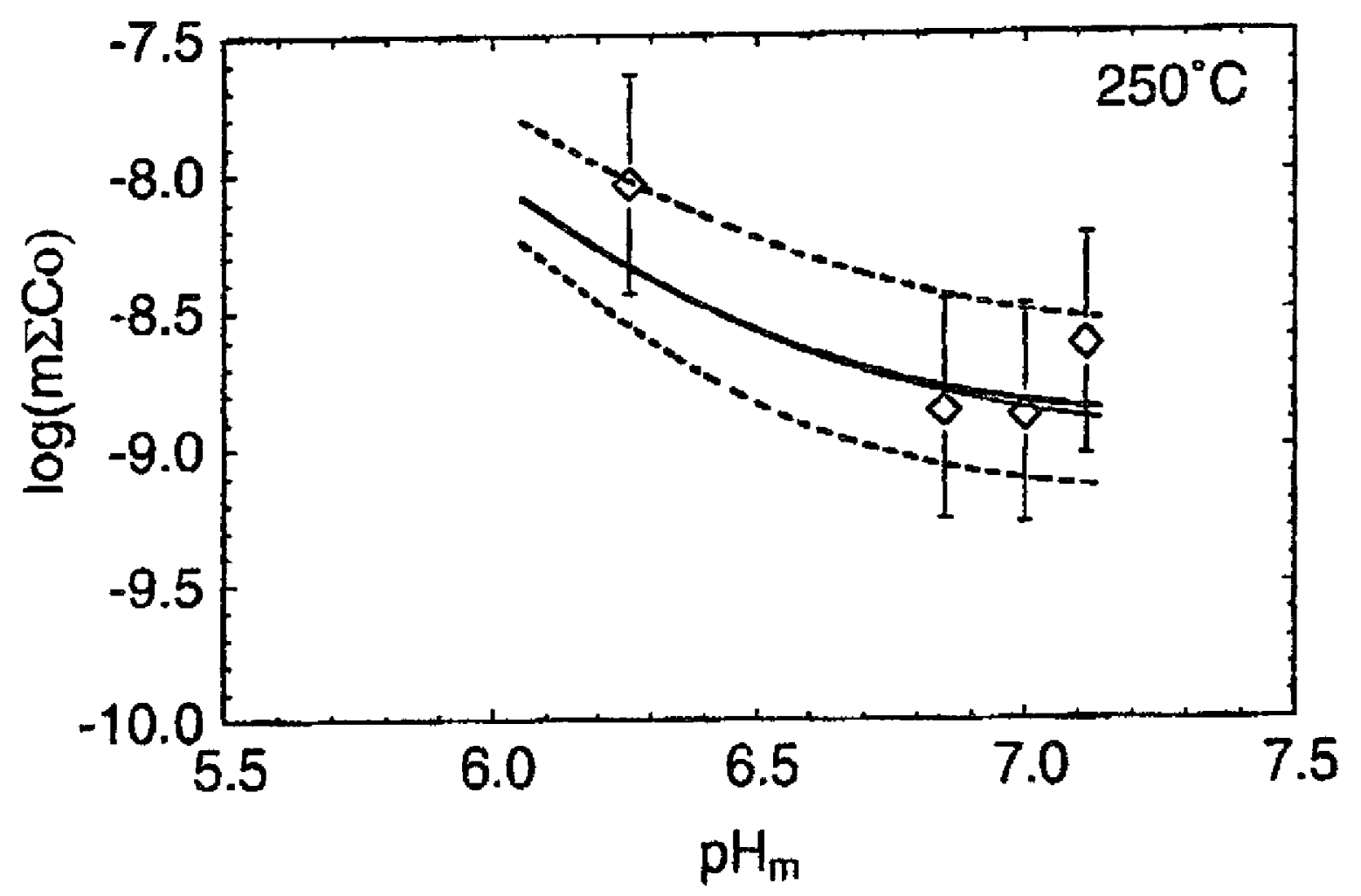

Figure 4 


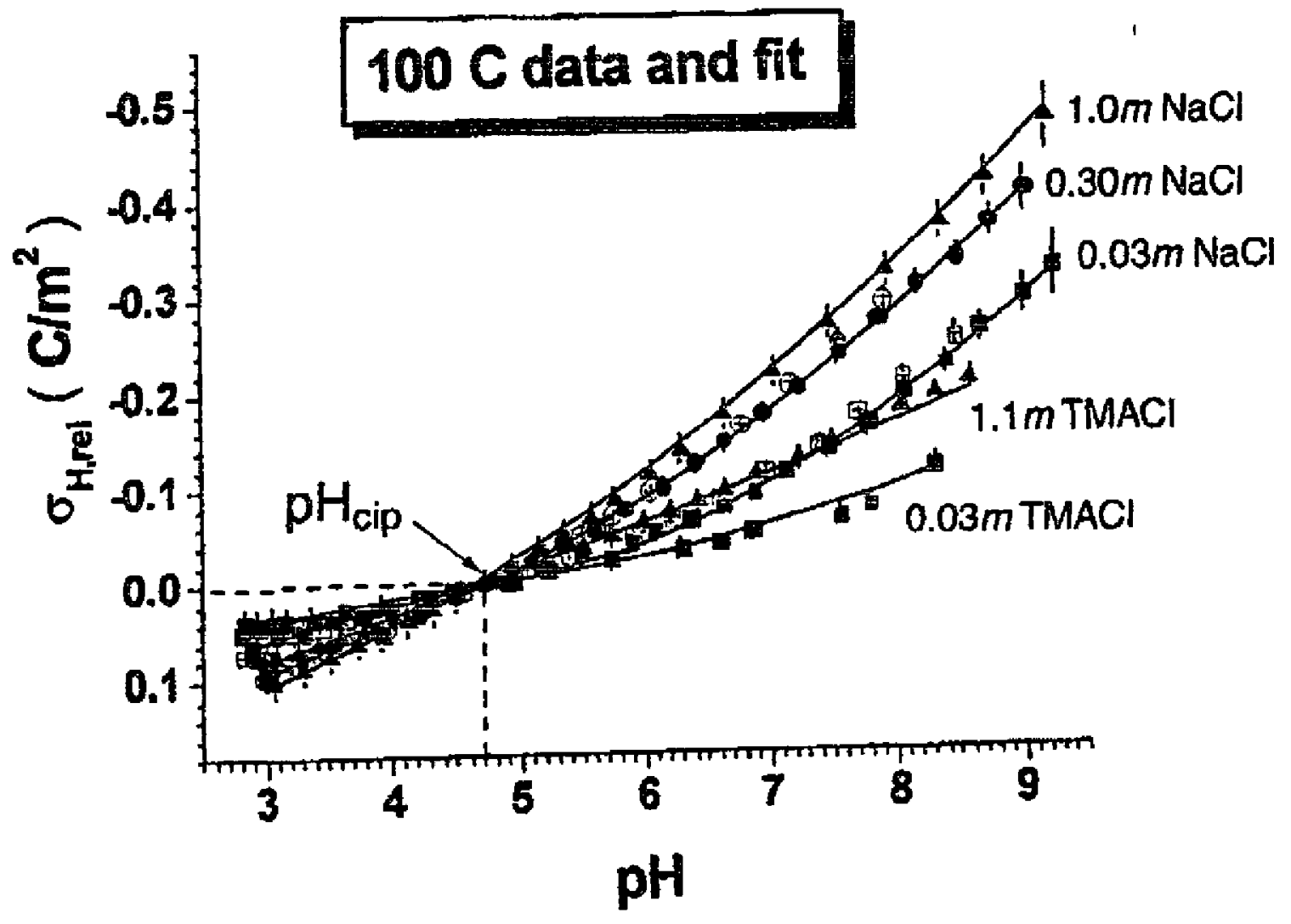

Figure 5 
Background-corrected surface titration at $100^{\circ} \mathrm{C}$

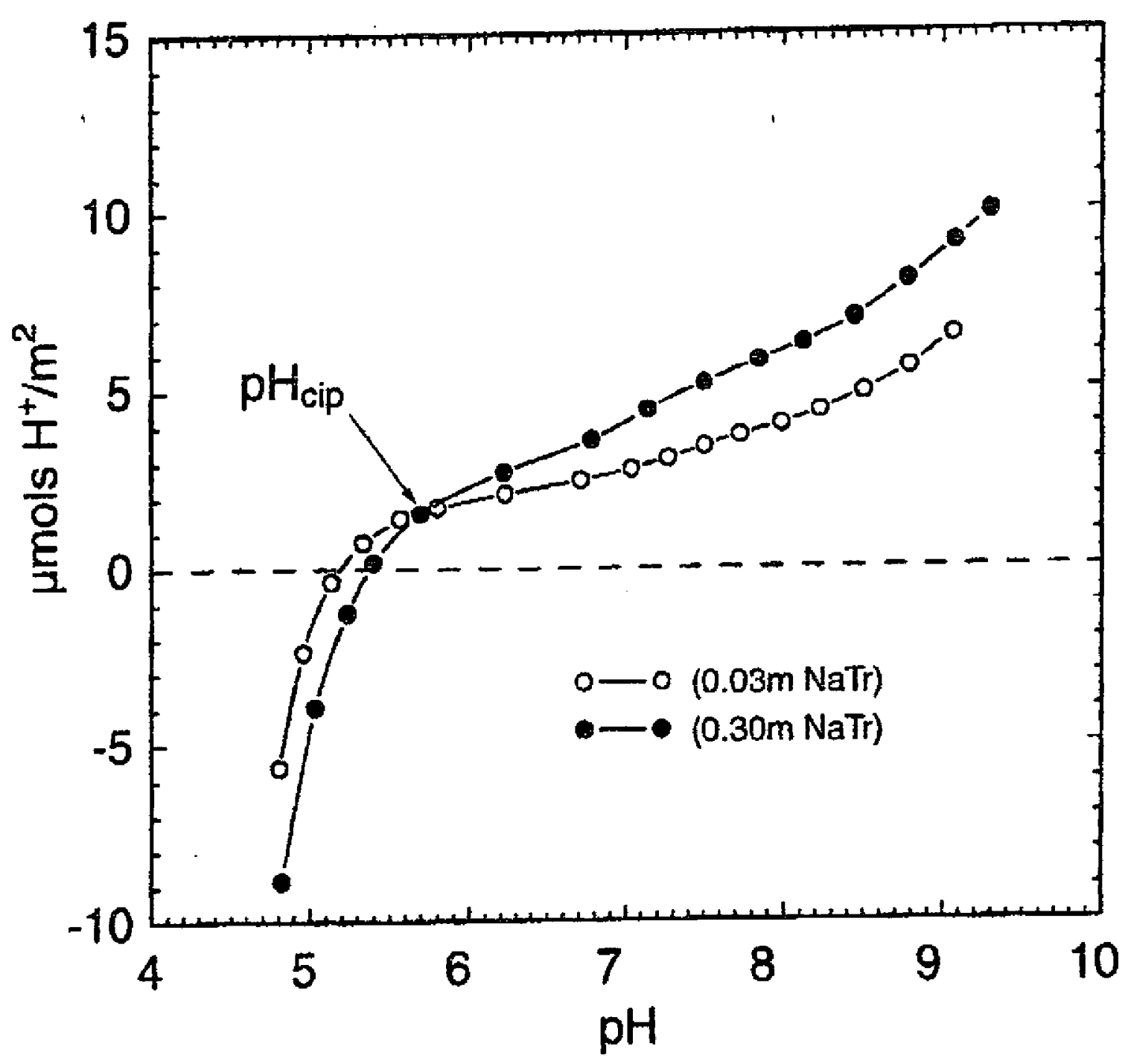

Figure 6 


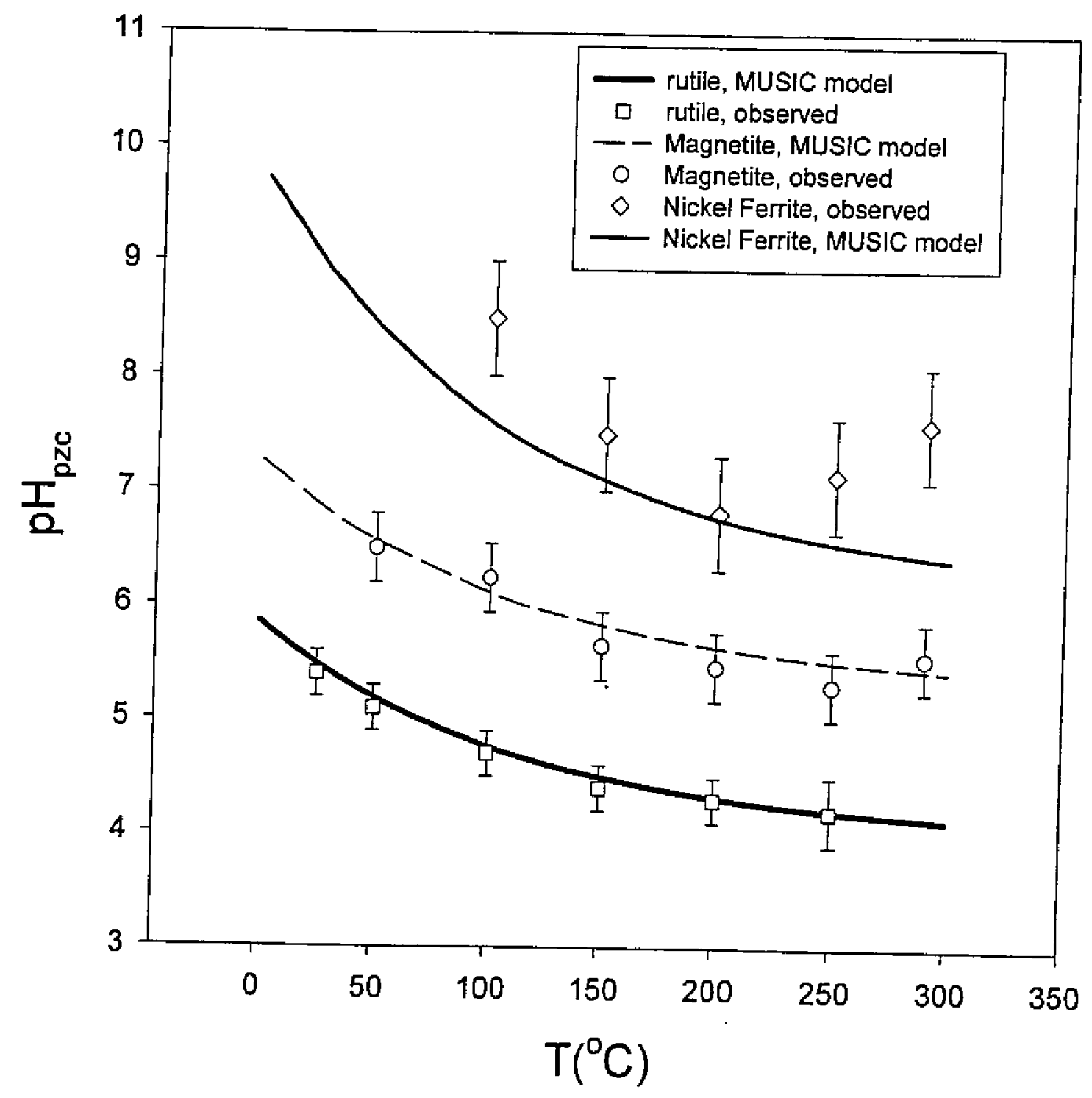



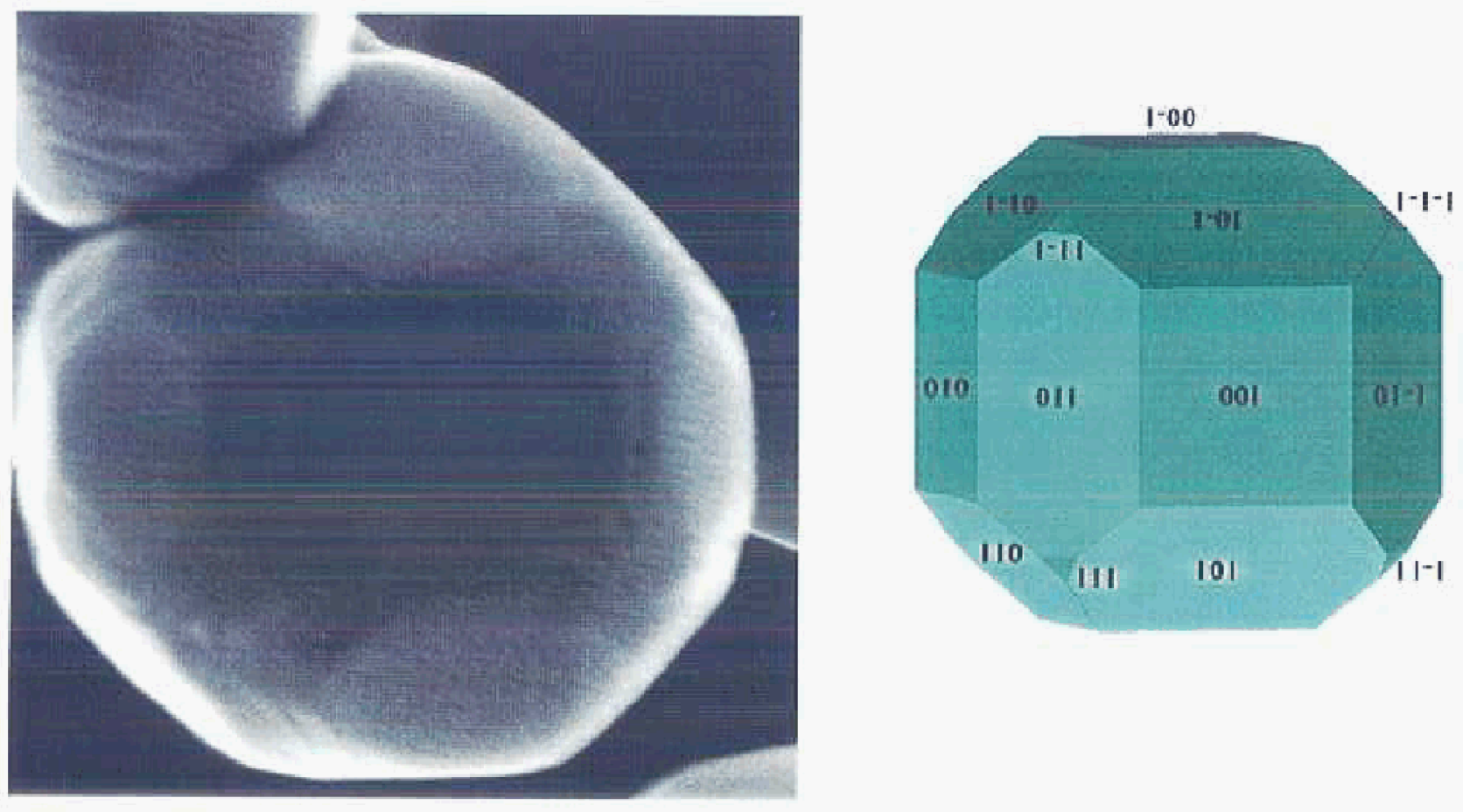

E.19V890 000 7NHO 


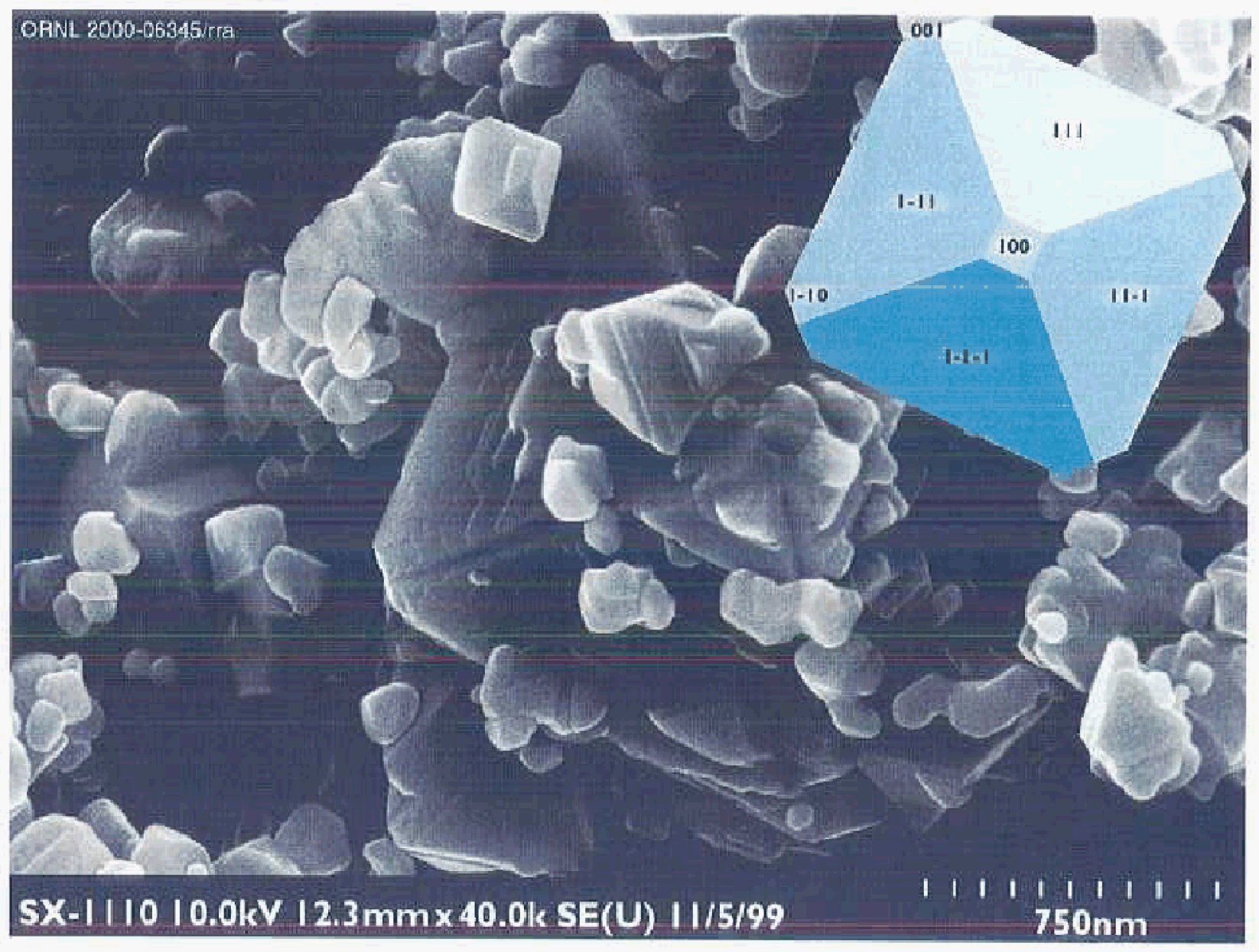

$\underbrace{\frac{\pi}{2}}_{0}-$ 


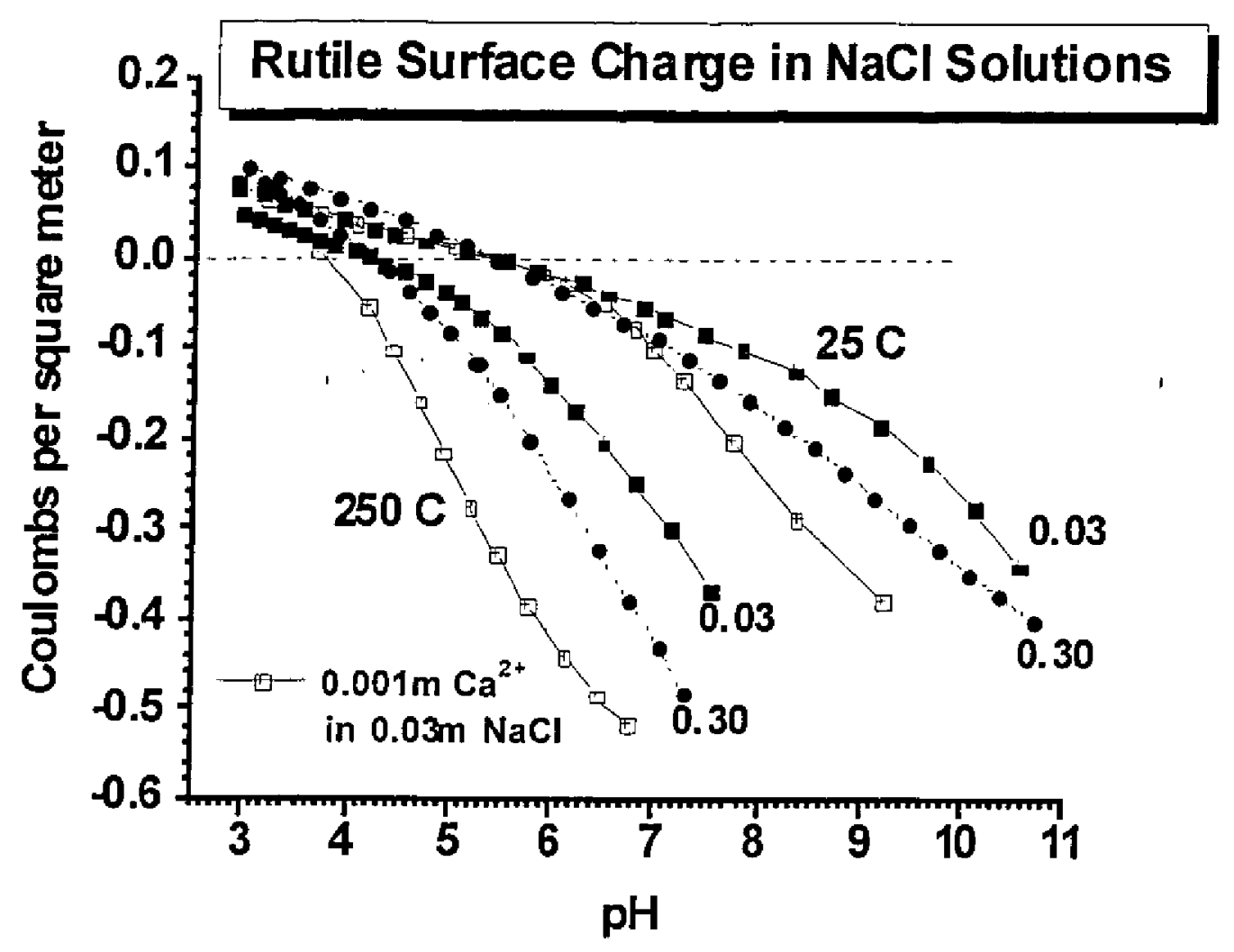




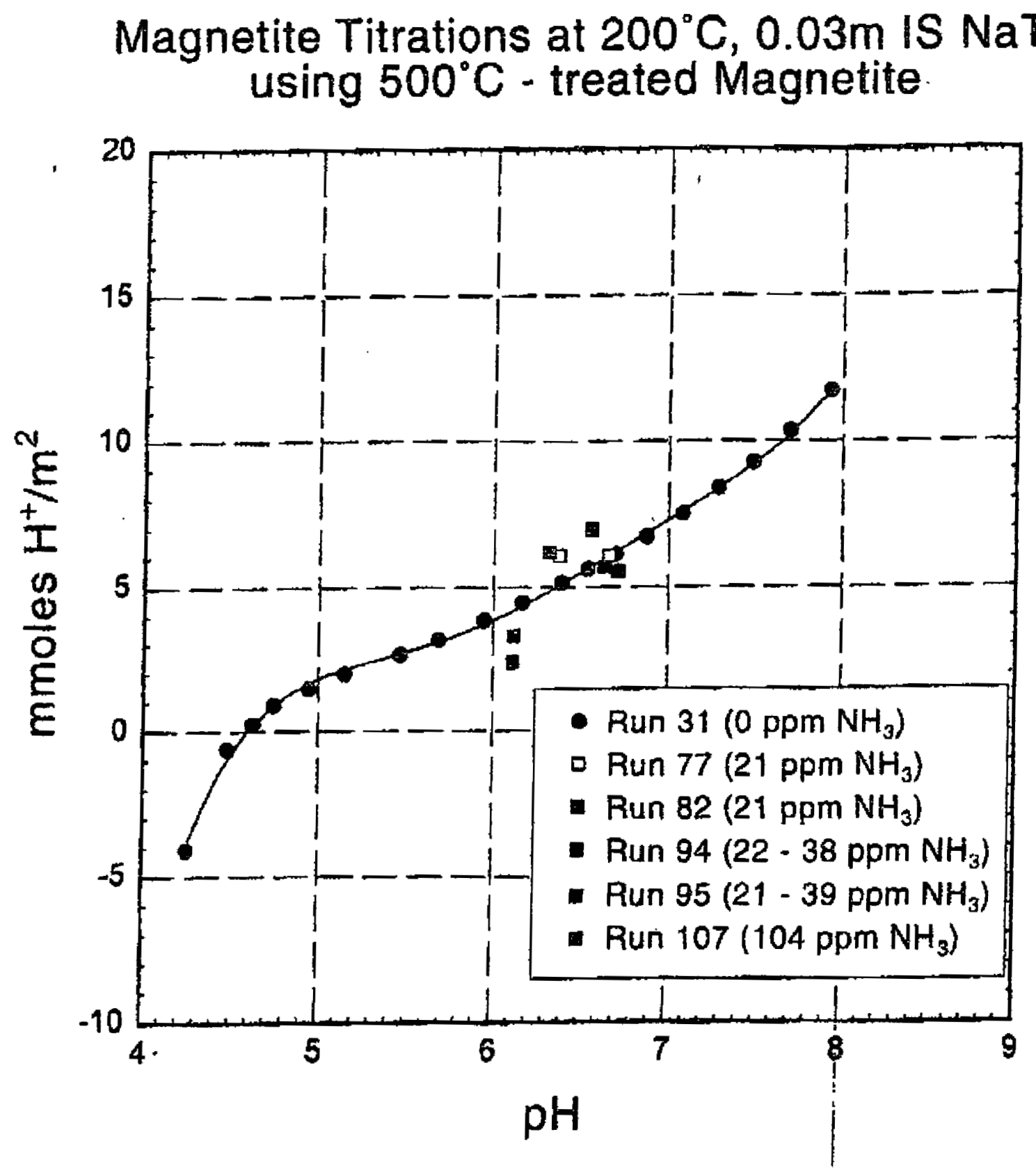

Figure 11 